\title{
Description of the cave organ in three species of the genus Belminus (Hemiptera: Reduviidae: Triatominae) by optical and scanning electron microscopy
}

\author{
Claudia Magaly Sandoval ${ }^{1 /+}$, Elsa Nieves ${ }^{1}$, Víctor Manuel Angulo ${ }^{2}$, Elis Aldana ${ }^{3}$ \\ 'Laboratorio de Parasitología Experimental, Departamento de Biología, Núcleo Pedro Rincón Gutiérrez \\ ${ }^{3}$ Laboratorio de Entomología Herman Lent, Facultad de Ciencias, Universidad de Los Andes, La Hechicera, 5101 Mérida, Venezuela \\ ${ }^{2}$ Centro de Investigaciones en Enfermedades Tropicales, Universidad Industrial de Santander, Piedecuesta, Santander, Colombia
}

The cave organ is a sensory receptor in the antenna pedicel of some Reduviidae. This paper describes this organ for the first time in three species of the genus Belminus, Belminus corredori, Belminus ferroae and Belminus herreri, by optical and scanning electron microscopy. The structures presented a general pattern similar to one reported for other species of Triatominae.

Key words: sensory organs - pedicellar structure - antenna

The cave organ was originally described in the pedicel of the antenna of Triatoma infestans by Barth (1952) but under the name of cova das cerdas because of the presence of numerous digitiform prolongations covering the internal surface (Catalá et al. 1998). This organ was defined by Barth (1952) as a cuticular invagination formed by a closed ellipsoidal cavity in the pedicel, with a thin connecting channel open at the invagination. Among the Triatominae, descriptions of this structure have been reported for 18 species of the genera Triatoma Laporte, 1832, Rhodnius Stål, 1859, Panstrongylus Berg, 1879, and Eratyrus Stål, 1859 (Barth 1952, Catalá 1994, Catalá et al. 1998, Weirauch 2003), but no description has been published for the genus Dipetalogaster Usinger, 1939 (Weirauch 2003). In other subfamilies of Reduviidae, such as Peiratinae, Reduviinae and Stenopodainae, the description of the cave organ has been reported by Weirauch (2003) and this structure is becoming a structure of value in the study of phylogenetic systematics of Reduviidae. This organ has not been recorded in the genus Belminus Stål, 1859, and here we describe this pedicellar structure in three species: Belminus herreri Lent and Wygodzinsky, 1979, Belminus corredori Galvão and Angulo 2006 and Belminus ferroae Sandoval, Pabón, Jurberg and Galvão 2007.

We used specimens of the three species of Belminus from laboratory colonies kept at a temperature of $24^{\circ} \mathrm{C} \pm$ $3^{\circ} \mathrm{C}$ and a relative humidity of $60 \% \pm 10 \%$. The insects were fed on Dictyoptera of the genus Blaberus Serville, 1831. The parental specimens of these colonies were captured in the following localities in Colombia: B. corredori in San Gil, department of Santander, in 2003, $B$. herreri in San Martín, department of Cesar, in 2001, and

Financial support: CDCHT-ULA (C-1604-08-03-A)

+ Corresponding author: magaly6@yahoo.com

Received 3 February 2011

Accepted 14 April 2011
B. ferroae in Toledo, department of Northern Santander, in 2004 (Sandoval et al. 2004, 2010, Galvão \& Angulo 2006). The antennae were removed at the scape for study by optical microscopy (OM), clarified with $10 \%$ $\mathrm{w} / \mathrm{v} \mathrm{KOH}$ for $1-2 \mathrm{~h}$ at $50^{\circ} \mathrm{C}$, washed with plenty of water, dehydrated in ethanol and immersed in phenol for half an hour. Five antennae were examined in each nymphal stage and in adults of both sexes for the three species under study. Drawings of the cave organ were made in under camera lucida at 40X. Even though T. infestans Klug, 1834 was not analysed in this paper, we included a drawing of its cave organ for the purpose of comparing it with the Belminus species cave organs studied here. For scanning electron microscopy (SEM), antennae of adults of both sexes were removed and directly mounted in a lateral position on a double-sided tape onto a metal support and then metallised with gold for $2 \mathrm{~min}$ in a SPIModule $^{\mathrm{TM}}$ operated at $10 \mathrm{~mA}$. The micrographs were taken with a Hitachi S-2500 electron microscope operated at $20 \mathrm{kV}$.

The species of Triatominae for which the cave organ has been studied are shown in Table I. This sensory structure was observed only in adults of both sexes in the three species of the genus Belminus; there was no apparent sexual dimorphism. The cave organ is located in the external lateral region, near the distal trichobothria, as reported for other Reduviidae (Barth 1952, Catalá 1994, Catalá et al. 1998, Weirauch 2003). Under OM, the cave organ shows three clearly differentiated areas: the opening, the tunnel and the main cavity (Fig. 1). In these three species, the opening is clearly sclerotised and is larger in size in B. ferroae (Fig. 2A, B). A heavily sclerotised tunnel is also observed, sometimes bent, which narrows down towards the end that connects to the main chamber; this chamber is clearly sub-spherical (Fig. 1). These characteristics contrast with those of species of Rhodnius, Triatoma and Panstrongylus which have a main chamber that is clearly enlarged (Catalá et al. 1998). By SEM, differences in the opening were also observed: $B$. corredori and B. herreri were smooth, 
in contrast to B. ferroae, which has a more ornamented tegument around the opening (Fig. 2). An opening with smooth borders is common in species of the genus Triatoma, and the opening is more ornamented in Rhodnius species (Catalá 1994). The opening structures were 7.4-14.8 $\mu \mathrm{m}$ in width for the species of Belminus (Table II), similar but less variable than the widths reported for the genera Rhodnius $(6-20 \mu \mathrm{m})$ and Triatoma (3-20 $\mu \mathrm{m})$ (Catalá 1994). The function of the cave organ remains controversial; Barth (1952) proposes that it is an infrared receptor. Other electrophysiological studies in T. infestans support this hypothesis (Lazzari \& Wicklein 1994). However, Catalá et al. (1998) states that the ultrastructure of the cave organ studied in five species of Triatominae is also consistent with an olfactory function and its position on the outer face of the pedicel, as well as its particular spatial pattern, suggests a possible role in monitoring molecules during flight. Catalá et al.

TABLE I

List of species of Triatominae that have had the cave organ studied by method and references

\begin{tabular}{|c|c|c|c|}
\hline Genus & Species & Approach & References \\
\hline \multirow[t]{7}{*}{ Triatoma } & T. infestans (Klug 1834) & OM, SEM, TEM, EAG & $\begin{array}{c}\text { Barth (1952), } \\
\text { Catalá (1994), } \\
\text { Lazzari and Wicklein (1994) }\end{array}$ \\
\hline & T. guasayana Wygodzinsky \& Abalos 1949 & SEM & Catalá (1994) \\
\hline & T. patagonica Del Ponte 1929 & SEM & Catalá (1994) \\
\hline & T. rubrovaria (Blanchard 1843) & $\mathrm{OM}$ & Catalá et al. (1998) \\
\hline & T. dimidiata (Latreille 1811) & $\mathrm{OM}$ & $\begin{array}{l}\text { Catalá et al. (1998), } \\
\text { Weirauch (2003) }\end{array}$ \\
\hline & T. protracta Uhler 1894 & OM & Catalá et al. (1998) \\
\hline & T. sordida (Stål 1859) & OM, SEM, TEM & $\begin{array}{c}\text { Barth (1952), } \\
\text { Catalá et al. (1998) }\end{array}$ \\
\hline \multirow[t]{2}{*}{ Panstrongylus } & P. megistus (Burmeister 1835) & $\mathrm{OM}$ & $\begin{array}{c}\text { Barth (1952), } \\
\text { Catalá et al. (1998) }\end{array}$ \\
\hline & P. geniculatus (Latreille 1811) & $\mathrm{OM}$ & Weirauch (2003) \\
\hline \multirow[t]{8}{*}{ Rhodnius } & R. pictipes Stål 1872 & SEM & $\begin{array}{l}\text { Catalá (1994), } \\
\text { Catalá and Schofield (1994) }\end{array}$ \\
\hline & R. neglectus Lent 1954 & SEM & $\begin{array}{l}\text { Catalá (1994), } \\
\text { Catalá and Schofield (1994) }\end{array}$ \\
\hline & R. nasutus Stål 1859 & SEM & $\begin{array}{l}\text { Catalá (1994), } \\
\text { Catalá and Schofield (1994) }\end{array}$ \\
\hline & R. prolixus Stål 1859 & OM, SEM & $\begin{array}{c}\text { Barth (1952), } \\
\text { Catalá (1994), } \\
\text { Catalá and Schofield (1994), } \\
\text { Weirauch (2003) }\end{array}$ \\
\hline & R. ecuadoriensis Lent \& Leon 1958 & SEM & $\begin{array}{l}\text { Catalá (1994), } \\
\text { Catalá and Schofield (1994) }\end{array}$ \\
\hline & R. paraensis Sherlock, Guitton \& Miles 1977 & SEM & $\begin{array}{l}\text { Catalá (1994), } \\
\text { Catalá and Schofield (1994) }\end{array}$ \\
\hline & R. pallescens Barber 1932 & SEM & $\begin{array}{c}\text { Catalá (1994), } \\
\text { Catalá and Schofield (1994) }\end{array}$ \\
\hline & R. neivai Lent 1953 & SEM & $\begin{array}{l}\text { Catalá (1994), } \\
\text { Catalá and Schofield (1994) }\end{array}$ \\
\hline Eratyrus & E. mucronatus Stål 1859 & $\mathrm{OM}$ & Weirauch (2003) \\
\hline Dipetalogaster & D. maxima ${ }^{a}$ (Uhler 1894) & $\mathrm{OM}$ & Weirauch (2003) \\
\hline \multirow[t]{3}{*}{ Belminus } & B. herreri Lent \& Wygodzinsky 1979 & OM, SEM & This paper \\
\hline & B. corredori Galvão \& Angulo 2006 & OM, SEM & This paper \\
\hline & B. ferroae Sandoval, Pabón, Jurberg \& Galvão 2007 & OM, SEM & This paper \\
\hline
\end{tabular}

a: without cave organ; EAG: electroantennogram; OM: optical microscopy; SEM: scanning electron microscopy; TEM: transmission electron microscopy. 
(1998) do not disregard the infrared function proposed by Barth (1952), instead assigning a double function to the cave organ. The discovery of this organ in apterous Reduviidae suggests that this structure works well for species with no or low dispersal capacity by flight (Weirauch 2003). B. corredori is the only species of the genus

A

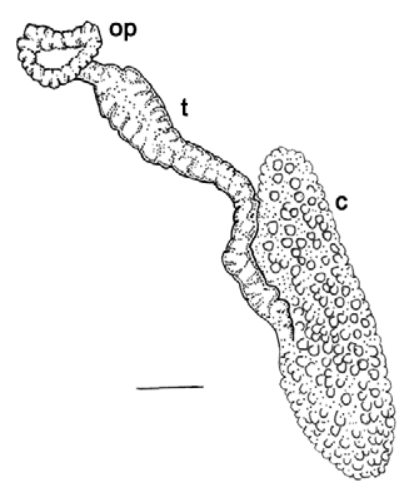

B

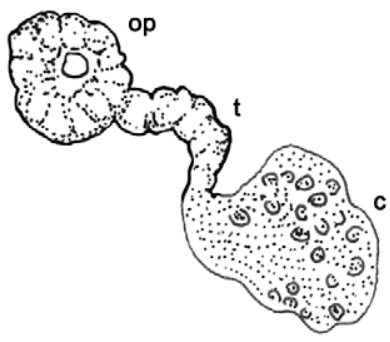

C

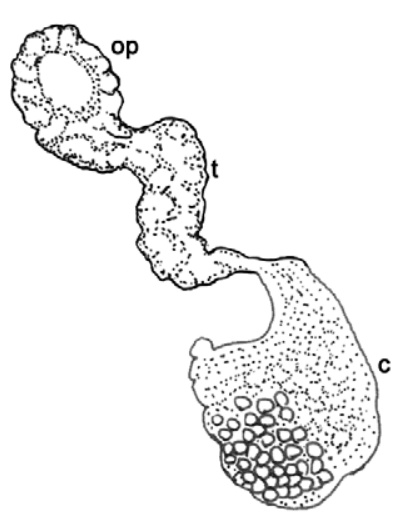

D

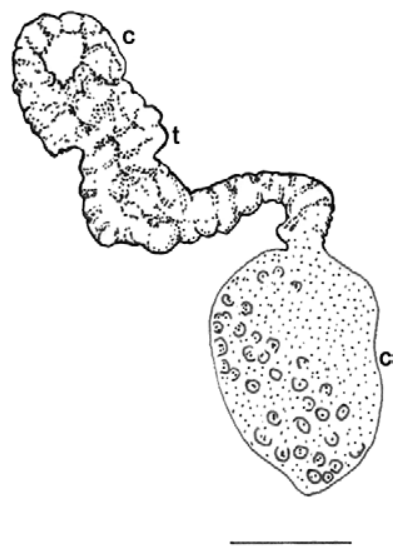

Fig. 1A: cave organ showing the opening (op), tunnel ( $\mathrm{t}$ ) and main cavity (c) in Triatoma infestans; B: in Belminus corredori; C: in Belminus ferroae; D: in Belminus herreri. $\mathrm{Bar}=20 \mu \mathrm{m}$. for which both sexes are brachypterous, but this species has a cave organ of similar development as the other two species of Belminus, which are macropterous.

For the first time, the description of the cave organ is reported for the genus Belminus with a main pattern similar to that described for other species of Reduviidae. Even though not all known species of the Belminus genus were analysed in this paper, we propose that the ornamentation around the opening and the dimensions and the design of the tunnel and of the chamber could be specific characteristics of the genus Belminus.
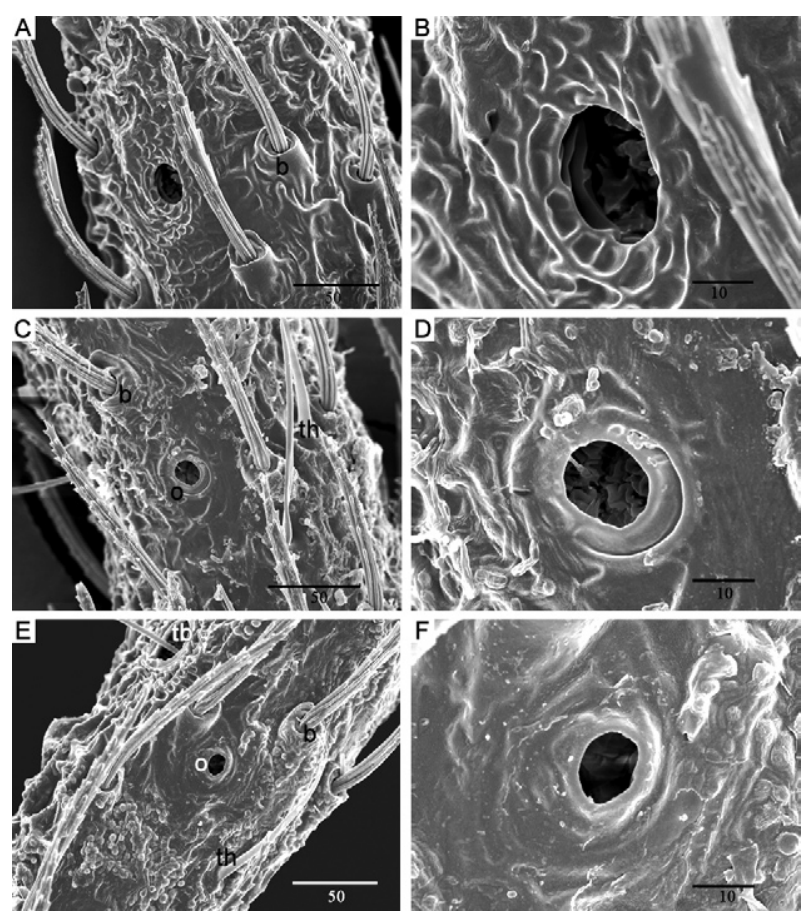

Fig. 2: external side of the second antennal segment (pedicel) showing the external opening of cave organ (o) 1,500-5,000X. A, B: Belminus ferroae; C, D: Belminus herreri; E, F: Belminus corredori; b: bristle; tb: distal trichobothria; th: thin-wall trichoid. Bar in microns.

\section{TABLE II}

Measurements in microns of the main structures of the cave organ in the three species of Belminus

\begin{tabular}{|c|c|c|c|}
\hline Structure & Belminus corredori & Belminus herreri & Belminus ferroae \\
\hline Opening (diameter major) & $\begin{array}{c}10.87 \\
(1.73,15.89)\end{array}$ & $\begin{array}{c}9.8 \\
(2.89,29.10)\end{array}$ & $\begin{array}{c}11.32 \\
(1.21,10.73)\end{array}$ \\
\hline Tunnel & $\begin{array}{c}29.39 \\
(5.64,19.18)\end{array}$ & $\begin{array}{c}37.87 \\
(9.69,25.58)\end{array}$ & $\begin{array}{c}29.64 \\
(5.63,19)\end{array}$ \\
\hline Cavity & $\begin{array}{c}24.21 \\
(4.00,16.52)\end{array}$ & $\begin{array}{c}32.11 \\
(7.95,24.77)\end{array}$ & $\begin{array}{c}33.35 \\
(5.12,15.36)\end{array}$ \\
\hline Total longitude & $\begin{array}{c}62.99 \\
(6.91,10.97)\end{array}$ & $\begin{array}{c}78.22 \\
(18.52,23.68)\end{array}$ & $\begin{array}{c}76.98 \\
(4.25,5.52)\end{array}$ \\
\hline
\end{tabular}

average, standard deviation and coefficient of variation in parenthesis. 


\section{REFERENCES}

Barth R 1952. Estudos anatômicos e histológicos sôbre a subfamília Triatominae (Hemíptera, Reduviidae). II. parte: Um nôvo órgão sensível das Triatominae. Mem Inst Oswaldo Cruz 1: 1-4.

Catalá S 1994. The cave organ of Triatominae (Hemíptera, Reduviidae) under scanning electron microscopy. Mem Inst Oswaldo Cruz 89: 275-277.

Catalá S, Schofield C 1994. Antennal sensilla of Rhodnius. J Morphol 219: 193-203.

Catalá S, Tomasi V, Hliba E, Rovasio R 1998. The cave organ in Triatominae (Hemiptera: Reduviidae) antennae: an olfactory receptor? Biocell 22: 1-7.

Galvão C, Angulo VM 2006. Belminus corredori, a new species of Bolboderini (Hemiptera: Reduviidae: Triatominae) from Departament of Santander, Colombia. Zootaxa 1241: 61-68.
Lazzari CR, Wicklein M 1994. The cave-like sense organ in the antennae of Triatominae bugs. Mem Inst Oswaldo Cruz 89: 643-648.

Sandoval CM, Duarte R, Gutierrez R, Rocha D da S, Angulo VM, Esteban L, Reyes M, Jurberg J, Galvão C 2004. Feeding sources and natural infection of Belminus herreri (Hemiptera, Reduviidae, Triatominae) from dwellings in Cesar, Colombia. Mem Inst Oswaldo Cruz 99: 137-140.

Sandoval CM, Ortiz N, Jaimes D, Lorosa E, Galvão C, Rodriguez O, Scorza JV, Gutiérrez R 2010. Feeding behaviour of Belminus ferroae (Hemiptera: Reduviidae), a predaceous Triatominae colonizing rural houses in Norte de Santander, Colombia. Med Vet Entomol 24: 124-131.

Weirauch C 2003. Pedicellar structures in Reduviidae (Heteroptera). Comments on cave organ and trichobothria. Eur J Entomol 100: 571-580. 